\title{
DNA viruses in the pathogenesis of sporadic chronic idiopathic intestinal pseudo-obstruction
}

\author{
H S Debinski, M A Kamm, I C Talbot, G Khan, H O Kangro, D J Jeffries
}

\begin{abstract}
Background-Hereditary forms of chronic idiopathic intestinal pseudo-obstruction (CIIP) are well described but the aetiology of most cases of sporadic CIIP is unknown. Aim-To determine whether herpes viruses can persist in the gastrointestinal tract, thereby implicating them in the
\end{abstract} pathogenesis of CIIP.

Methods-Twenty one specimens of small and large intestine from 13 patients with CIIP (eight visceral myopathy, three visceral neuropathy, two undifferentiated), and 12 patients operated on for colorectal cancer (controls) were examined for evidence of Herpesvirus DNA (cytomegalovirus, Epstein-Barr virus (EBV), herpes simplex virus type 1 , and varicella zoster virus) by nested polymerase chain reaction (PCR) and in situ DNA hybridisation (ISH) to localise signal to the muscularis propria or myenteric plexus. Results-Screening with nested PCR produced three patients with positive results. One patient with an inflammatory visceral neuropathy had EBV detected in the small intestine by PCR, and ISH demonstrated localisation to neurones in the myenteric plexus. A patient with a visceral myopathy had EBV DNA in both the small and large intestine; and one patient with a visceral neuropathy had small intestine positive for CMV DNA (both negative by ISH). No control tissue was positive for any virus.

Conclusions-In individual patients there appears to be evidence linking a viral aetiology to sporadic CIIP. The role of neurotropic viruses in acute and chronic motility disturbances needs further study. (Gut 1997; 41: 100-106)

St Mark's Hospital, London

H S Debinski

M A Kamm

I C Talbot

Department of Virology, St Bartholomew's Hospital, London G Khan H O Kangro D J Jeffries

Correspondence to: Dr Michael A Kamm St Mark's Hospital, Northwick Park, Watford Road, Harrow, Middlesex HA1 3UJ.

Accepted for publication 24 February 1997 emerged of a more extensive panenteric disorder. Smooth muscle or nerves in the oesophagus, the stomach, and also the biliary system $^{3}$ and the colon can be affected. In some patients the urinary tract is also involved.
Chronic idiopathic intestinal pseudo-obst syndrome characterised by recurrent episodes apparent intestinal obstruction affecting part of the gastrointestinal tract in the absence
Since the term CIIP was first coined by Dudley et al in $1958^{5}$ there has emerged clear evidence that this disorder represents the common end point of a range of pathologies. Overall $25 \%$ of cases of CIIP are familial ${ }^{6}$ and the remainder sporadic. The pathogenesis of sporadic forms is poorly understood although in most patients there are clear structural abnormalities of the myenteric plexus (visceral neuropathy) ${ }^{7}$ or muscularis propria (visceral myopathy). ${ }^{8} 9$

Visceral myopathies may exist in familial forms, with autosomal dominant and recessive modes of inheritance, and in sporadic forms. A range of abnormalities of muscle function has been described including degenerative myopathies, ${ }^{8}$ abnormalities of smooth muscle mitochondrial function, ${ }^{10-12}$ and a developmental contractile abnormality of smooth muscle protein. ${ }^{13}$ Visceral neuropathies may be familial but most are sporadic. The advent of a silver stain technique for studying pathological alterations of the myenteric plexus ${ }^{14}$ has resulted in the understanding that most are degenerative in morphology though some may be associated with inflammatory changes within the plexus.

The relationship between possible viral infection and disturbances of gastrointestinal motility is an area which has not been explored systematically. Motility disorders such as CIIP often evolve sporadically and are of obscure aetiology. In all categories there may be associated abnormalities of the autonomic nervous system in up to $30 \%$ of patients ${ }^{15}$ and symptoms may be heralded by a poorly defined illness. Much of this could be explained by a systemic viral infection acting permanently to alter normal peristaltic activity via effects on the myenteric plexus, extrinsic enteric neurones, or directly on enteric muscle. An example of an infective aetiology leading to myenteric plexus destruction and gut dilatation is Chagas' disease; this damage may be mediated by cross reacting antibodies.

We examined the possibility that herpes viruses may be aetiologically important in the genesis of CIIP in some patients without a family history of this condition. Seven herpes viruses are known to infect man: herpes simplex virus 1 and 2, varicella zoster virus (VZV), cytomegalovirus (CMV), herpes simplex virus 6 and 7, and Epstein-Barr virus (EBV). These viruses were evaluated as they are known to be neurotropic, they establish latent infection which may last the lifetime of the host, and evidence has linked them to the pathogenesis of motility disorders. Varicella zoster virus has been identified by in situ DNA 
hybridisation in the myenteric plexus of patients with achalasia ${ }^{16}$; this is consistent with the neurotropic characteristics of this virus. There is also evidence linking herpes viruses with the pathogenesis of CIIP. Clinical case reports of CIIP relying on conventional viral serology and tissue localisation of viral inclusions in the myenteric plexus have been described for EBV, ${ }^{17} \mathrm{VZV},{ }^{18}$ and $\mathrm{CMV} .{ }^{19-21}$

Serology is a poor tool for diagnosis of herpes virus infection as these viruses are widespread, isolated frequently, and levels of antibodies do not correlate well with disease state. By searching for evidence of herpes virus DNA in the intestinal tissue of patients with CIIP utilising the polymerase chain reaction (PCR) and in situ DNA hybridisation (ISH), we attempted to address the question of whether herpes viruses can persist in the gastrointestinal tract and localise to the muscularis propria or myenteric plexus, thereby implicating them in the pathogenesis of this disorder.

\section{Materials and methods}

PATIENTS

Tissue from 13 patients with sporadic CIIP diagnosed and treated at St Mark's Hospital was examined for evidence of viral DNA. The mean age of patients was 37 years (range 20-63); there were seven males and six females. These were patients who presented with chronic, recurrent abdominal pain associated with episodic nausea, vomiting, constipation, and abdominal distension with features of intestinal obstruction. Where possible the diagnosis of CIIP was confirmed by clinical, radiological, histological, and manometric and electrogastrographic criteria. ${ }^{22}$ All patients had evidence of upper and lower gut dilatation on barium studies and at laparotomy when mechanical obstruction was excluded. Exclusion criteria included patients with familial visceral neuropathy or myopathy, scleroderma, endocrine disorders (hypothyroidism, diabetes, hypoparathyroidism), and possible drug related CIIP.

The mean age for development of the first symptoms of CIIP was 29 years of age. Fifty four per cent of patients described an acute illness that was temporally related to the beginning of their subsequent chronic illness with multiple surgical procedures and extensive intestinal resection in the majority of cases (table 1). No patient could recall a respiratory illness or an infectious mononucleosis like syndrome but at the outset the four common symptoms described were vomiting, diarrhoea, constipation, and abdominal pain.

Many of these patients had undergone multiple surgical procedures to facilitate gastric

TABLE 1 Previous surgery in the 13 patients with CIIP

\begin{tabular}{llllll}
\hline Group & $\begin{array}{l}\text { Number of } \\
\text { patients }\end{array}$ & $\begin{array}{l}\text { Laparotomy } \\
\text { and biopsy }\end{array}$ & $\begin{array}{l}\text { Gastric } \\
\text { surgery }\end{array}$ & $\begin{array}{l}\text { Partial } \\
\text { enterectomy }\end{array}$ & Colectomy \\
\hline Visceral myopathy & 8 & 0 & 6 & 7 & 7 \\
Visceral neuropathy & 3 & 0 & 0 & 2 & 3 \\
Undifferentiated & 2 & 1 & 0 & 1 & 0 \\
\hline
\end{tabular}

and duodenal drainage, to deal with static loops of small bowel by enterectomy, and to manage intractable constipation by subtotal or total colectomy with or without formation of a stoma. Formalin fixed, paraffin wax embedded tissues were retrieved from the Pathology Department at St Mark's Hospital. These consisted of 21 specimens of surgically resected small and large intestine from 13 patients. Of these 13 patients, eight had specimens from both small and large intestine evaluated while the other five had intestinal tissue from small or large intestine alone examined. Light microscopy revealed that eight patients had a visceral myopathy and three a visceral neuropathy (table 1); two patients remained undifferentiated. One had motility changes consistent with a visceral neuropathy but subtle myopathic changes on small intestinal biopsy, and the other had gross bowel dilatation at enterectomy but no definite histological abnormality of the myenteric plexus or muscularis propria. Although only non-specific histological abnormalities were noted in these two patients, an apparently normal appearance does not exclude neuropathy or functional myopathy in the appropriate clinical setting if the bowel is dilated.

\section{Patient $R A$}

This 25 year old female who presented with severe constipation in her teens required regular faecal disimpaction. Radiological investigations initially demonstrated a megarectum dealt with by resection and a coloanal anastomosis. However she failed to improve symptomatically and further radiological studies revealed duodenal dilatation, confirming the presence of an extensive enteric motility disorder involving the upper and lower intestine (fig 1). She has subsequently had a megacolon resected and an end ileostomy fashioned. Histology of the distal small bowel and colon revealed a chronic inflammatory infiltrate involving the myenteric plexus consistent with a visceral neuropathy (fig 2). Ongoing problems consist of abdominal pain, vomiting, abdominal distension, and ileostomy dysfunction. A percutaneous feeding gastrostomy has been used for nutritional support when required.

\section{Control tissue}

Tissue was also studied from 12 patients who had undergone colonic resection for carcinoma. The tissue was from seven male and five female patients, mean age 61 years (range 44-72). Studied tissue was as far away as possible from the tumour and both macroscopically and histologically normal.

\section{POLYMERASE CHAIN REACTION}

\section{DNA extraction}

Paraffin wax blocks were cut using a Leitz microtome; four sections of $10 \mu \mathrm{m}$ thickness were dewaxed with xylene, spun in a microfuge at $13000 \mathrm{rpm}$ for 10 minutes, and the 
xylene discarded. The resultant pellet was rinsed with $95 \%$ cold ethanol and spun at $13000 \mathrm{rpm}$ for a further 10 minutes. The ethanol was then discarded and the step repeated to ensure all the xylene had been removed. The pellet was dried in a heating block at $45^{\circ} \mathrm{C}$ and resuspended in sterile distilled water.

Digestion was performed using $0.5 \mathrm{mg} / \mathrm{ml}$ of proteinase $\mathrm{K}$ incubated at $37^{\circ} \mathrm{C}$ for 12 hours. Phenol chloroform was added to the samples, which were mixed by inversion and then centrifuged at $13000 \mathrm{rpm}$ for 15 minutes. The aqueous supernatant phase was collected and the phenol layer discarded. To the aqueous phase was added $0.3 \mathrm{M}$ sodium acetate, $3 \mu \mathrm{l}$ tRNA, and ethanol. This was mixed and left to precipitate at $70^{\circ} \mathrm{C}$ for 20 minutes. The tubes were spun for 15 minutes at $4^{\circ} \mathrm{C}, 13000 \mathrm{rpm}$ to pellet the DNA and the ethanol was discarded. The pellet was then washed in $70 \%$ ethanol and centrifuged for a further five minutes at $13000 \mathrm{rpm}$. The pellet was then dried and resuspended in sterile distilled water, boiled for 15 minutes, and was then ready for use in the PCR reaction.

\section{Two step (nested) PCR}

The PCR was performed as described by Saiki et $a l,{ }^{23}$ using recombinant DNA polymerase from Thermus aquaticus (Amplitaq, PerkinElmer Cetus) and following the manufacturer's protocol. All preparative work for the PCR was carried out in an ultraviolet irradiated class II microbiological safety cabinet, using autoclaved plastic tubes and pipette tips throughout.

Amplification reactions were carried out in a total volume of $100 \mu \mathrm{l}$ comprising $50 \mu \mathrm{l}$ test sample and $50 \mu$ l reaction buffer in $0.6 \mathrm{ml}$ microcentrifuge tubes. The reaction buffer was prepared in bulk mastermix at double strength to give final concentrations of $50 \mathrm{mM} \mathrm{KCl}, 10$ $\mathrm{mM}$ Tris- $\mathrm{HCl}$ (pH 8.3), 2.0 mM $\mathrm{MgCl}_{2}$, $0.01 \%$ gelatin, $0.2 \mathrm{mM}$ of each deoxynucleoside triphosphate (dNTP), and $0.2 \mu \mathrm{M}$ of each oligonucleotide primer and stored at $-20^{\circ} \mathrm{C}$.

The required quantity of mastermix was thawed and the Amplitaq was added to give a final concentration of $2.5 \mathrm{U}$ per reaction tube. The reaction mixture was dispensed into 0.6 $\mathrm{ml}$ microcentrifuge tubes and the test sample

TABLE 2 Primers for PCR

\begin{tabular}{|c|c|c|c|c|}
\hline $\begin{array}{l}\text { Viral } \\
\text { gene }\end{array}$ & Sequence & $\begin{array}{l}\text { PCR product } \\
\text { (base pairs) }\end{array}$ & & Oligonucleotides sequence $\left(5^{\prime}-3^{\prime}\right)$ \\
\hline \multirow[t]{3}{*}{ EBV } & EBNA-1 & 221 & 1 & \multirow{9}{*}{$\begin{array}{l}\text { GCC GTC TCC TTT AAG TGT GA } \\
\text { ATG TCT TGG CCC TGA TCC TG } \\
\text { CCA GGT ACA GGA CCT GGA AA } \\
\text { GTC CTC GTC CAT GGT TAT CA } \\
\text { CTG TCG GTG ATG GTC TCT TC } \\
\text { CCC GAC ACG CGG AAA AGA AA } \\
\text { TCT CTG GTC CTG ATC GTC TT } \\
\text { GTG ACC TAC CAA CGT AGG TT } \\
\text { GTA CGG TTT TAC TGG AGT TG } \\
\text { CCG TAT CTC CAT ATA TAA CC } \\
\text { CCT CGT ACG CTT TTT GGG AG } \\
\text { TCT GCC ATG TTT ATA CGT AG } \\
\text { ACA GTA CGG CCC CGA GTT CGT GA } \\
\text { TTCCTGGAC TCC GAT AGC GCTGTAG } \\
\text { TTC TTG CTG GCC AAG CTG ACG G } \\
\text { AGC TTG TAG CTC GAG AGC TTG A }\end{array}$} \\
\hline & & 112 & $\begin{array}{l}2 \\
3\end{array}$ & \\
\hline & & & & \\
\hline \multirow[t]{2}{*}{ CMV } & (mtr II) & 234 & $\begin{array}{l}1 \\
2\end{array}$ & \\
\hline & & 168 & $\begin{array}{l}3 \\
4\end{array}$ & \\
\hline \multirow[t]{2}{*}{ VZV } & Pol 1 & 215 & 1 & \\
\hline & Pol 2 & 161 & 3 & \\
\hline \multirow[t]{2}{*}{ HSV } & Pol 1 & 346 & 1 & \\
\hline & Pol 2 & 200 & $\begin{array}{l}3 \\
4\end{array}$ & \\
\hline
\end{tabular}

was added, either neat or diluted with sterile distilled water, using sterile $50 \mu \mathrm{l}$ glass capillaries. The reaction mixtures were overlaid with mineral oil to prevent evaporation. Reaction tubes containing positive and negative viral DNA control samples were included in each batch of tests. Nested PCR for CMV, EBV, HSV type 1, and VZV was performed in a DNA thermal cycler (Perkin-Elmer Cetus) using the primer sequences shown in table 2 and the following amplification procedures.

The samples were amplified through 20 cycles consisting of denaturation at $94^{\circ} \mathrm{C}$ for one minute, annealing at $60^{\circ} \mathrm{C}$ for one minute, and primer extension at $72^{\circ} \mathrm{C}$ for two minutes. Aliquots of $5 \mu \mathrm{l}$ of amplified products were added to $45 \mu \mathrm{l}$ of sterile distilled water and transferred in a separate room to fresh reaction tubes, containing standard mastermix with 2.5 $\mathrm{U}$ of Taq polymerase, and $1.0 \mu \mathrm{M}$ of each of the nested primers; the reactions were then performed, according to the standard protocol, for 30 cycles.

\section{Gel electrophoresis of the PCR products}

After PCR amplification the products were transferred to a separate laboratory where they were collected with sterile $100 \mu \mathrm{l}$ glass capillaries and $8 \mu$ l aliquots were mixed with $2 \mu l$ of loading buffer $(0 \cdot 25 \%$ bromophenol blue, $30 \% \mathrm{wt} / \mathrm{vol}$ glycerol in water). Electrophoresis through a $2 \%$ agarose gel (Sigma, UK) at 100 volts was performed with $10 \mu$ l of each mixture. A sample of $\phi X 174$ RF DNA digested by HaeIII (Gibco BRL) was included on each gel as a DNA size marker. After electrophoresis, the gels were stained with ethidium bromide for 15 minutes at room temperature, destained with distilled water for 15-30 minutes, and visualised under an ultraviolet transilluminator (UVP Inc., USA). The gels were photographed using a Polaroid DS34 camera and Polaroid T667 film (Sigma).

\section{Virus strains}

Positive control material consisted of DNA prepared from human foreskin fibroblasts (HFF) infected with CMV (strain C-81), VZV (H-551), or HSV1 (TC-50). EBV was prepared from chronically infected B95-8 cells (obtained from ECACC, Porton Down). With the exception of EBV, all were clinical isolates routinely used in the Department of Virology at St Bartholomew's Hospital. The CMV isolate was originally from an aborted fetus with congenital CMV infection. VZV was from a patient with herpes zoster ${ }^{24}$ and the HSV1 isolate from a patient with gingivostomatitis.

\section{Oligonucleotide primers}

Oligonucleotide primers (table 2) from the Department of Virology were custom synthesised using the $380 \mathrm{~B}$ or 391 DNA synthesisers (Applied Biosystems). The oligonucleotides were deprotected after synthesis, precipitated with ethanol, and used without further purification. 
IN SITU HYBRIDISATION

Tissue

Formaldehyde fixed paraffin wax embedded material from the above cases of CIIP was used. Those selected were from the three patients positive by PCR, and patients who were negative but had a clear acute onset of symptoms leading to CIIP. Positive controls consisted of an EBV transformed cell line and a case of Hodgkin's disease known to be EBV positive by in situ hybridisation (ISH). The Ramos cell line (EBV negative) served as a negative control. For CMV, infected and uninfected fibroblasts were used as controls.

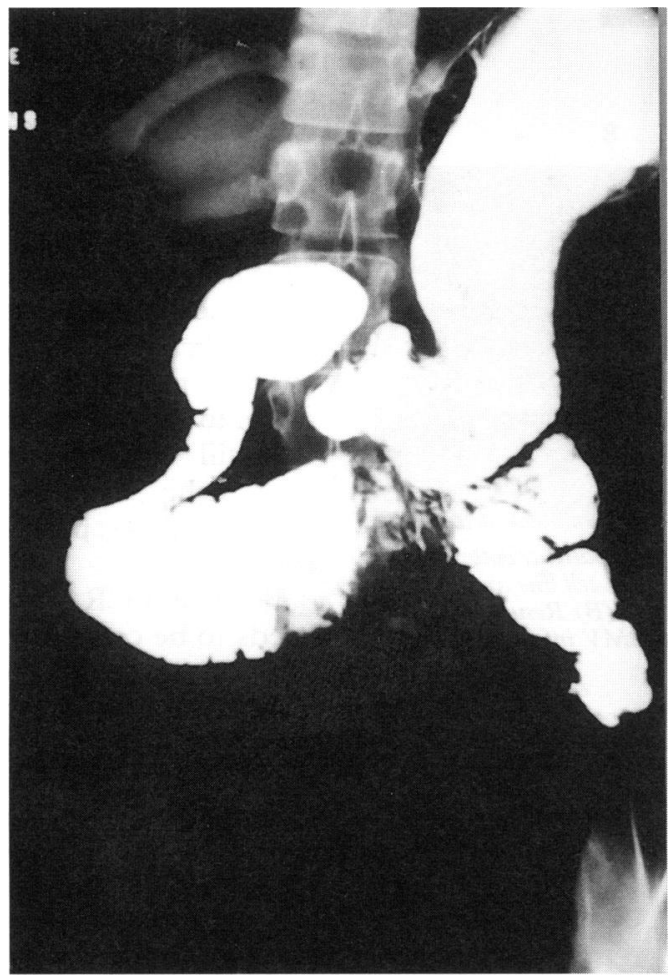

Figure 1: Contrast radiology of patient $3(R A)$ demonstrating the characteristic dilated duodenal loop seen in CIIP.

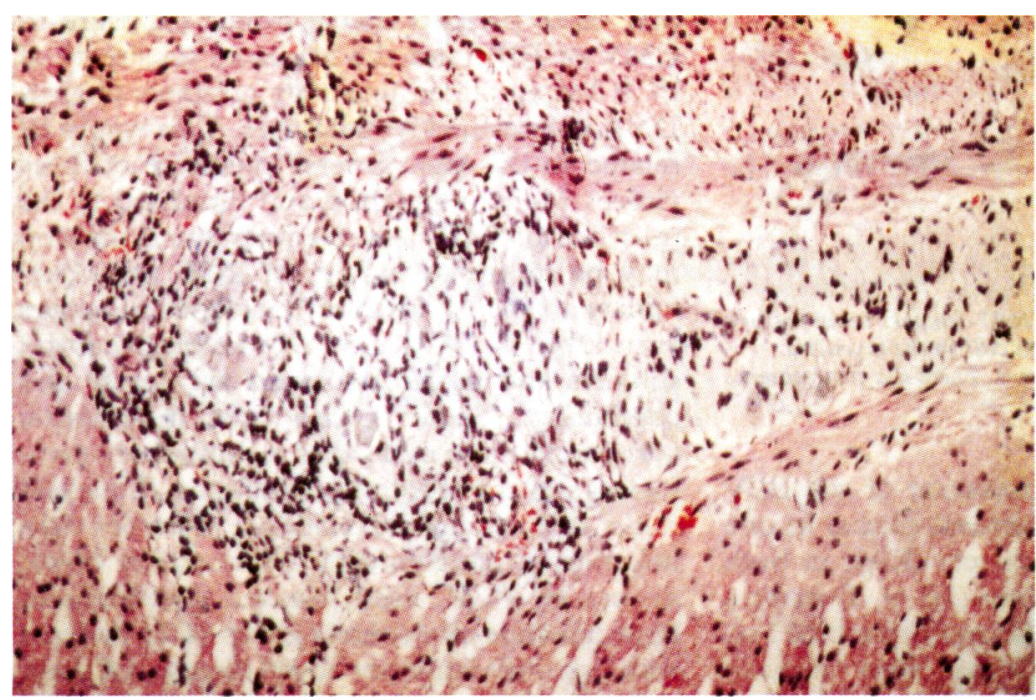

Figure 2: Haematoxylin and eosin stain (high power view) of the myenteric plexus of patient $3(R A)$ demonstrating positive signal for $E B V$. She has a dense inflammatory infiltrate selectively involving the myenteric plexus.
Preparation of probes

Two 30 mer oligonucleotide probes targeted against Epstein-Barr encoded small RNAs (EBER-1 and EBER-2) were synthesised and end labelled with digoxigenin-11-dUTP (Boehringer Mannheim, Lewes, UK). The sequences were designed to be complementary, targeting regions in EBER-1 and EBER-2, which are not bound to cellular proteins and do not contain significant secondary structure, thereby facilitating the efficiency of hybridisation. A 30 mer oligonucleotide, unrelated to EBER sequence, but having similar G-C content, was used as a negative control. Digoxigenin labelled antisense oligonucleotide probes corresponding to EBER-1 and EBER-2 have previously been demonstrated to be more sensitive than other in situ techniques for detecting EBV in the latent phase of replication. ${ }^{25}$ The CMV DNA probe consisted of HindIII $O$ fragment cloned in the plasmid pAT153. The probe was labelled with digoxigenin-11-dUTP by nick translation using a commercially available kit (Gibco, Paisley, UK).

\section{Hybridisation}

On sialinised slides, $5 \mu \mathrm{m}$ sections were heated for one hour at $70^{\circ} \mathrm{C}$, dewaxed in xylene, and endogenous peroxidase activity blocked with $0.5 \%$ hydrogen peroxide in methanol. The sections were digested with proteinase $\mathrm{K}$ in Tris buffered saline ( $\mathrm{pH} \mathrm{7.6)}$ for 15 minutes at $37^{\circ} \mathrm{C}$, dehydrated, and dried. The EBER probes were diluted to a concentration of 100 $\mathrm{ng} / \mathrm{ml}$ in hybridisation medium $(50 \%$ formamide, $5 \%$ dextran sulphate, $2 \times$ SSC) and the CMV probes to $1 \mu \mathrm{g} / \mathrm{ml}$. A $10 \mu \mathrm{l}$ quantity of the diluted probe was spotted onto the tissue sections and a coverslip placed on top. Probe and target EBER RNA or CMV DNA were simultaneously denatured at $104^{\circ} \mathrm{C}$ in a microwave oven (Toshiba ER-665) for eight minutes and the sections subsequently hybridised at $42^{\circ} \mathrm{C}$ overnight in a hot air oven.

Post-hybridisation washes consisted of two 10 minute washes in each of the following: $2 \times$ SSC (sodium citrate, sodium chloride) at room temperature, $0 \cdot 1 \times \mathrm{SSC}$ at $55^{\circ} \mathrm{C}$, and $2 \times \mathrm{SSC}$ at room temperature. The hybridisation signal was detected by a three layer ABC peroxidase technique (Vector Laboratories, Peterborough, UK) using mouse antidigoxin monoclonal antibody (Sigma, UK). Diaminobenzidine tetrachloride (DAB) was used as the chromogen. ${ }^{26}$

\section{Results}

Initial screening with nested PCR produced three patients with positive results (fig 3). One patient with a visceral neuropathy (patient RA) had EBV detected in the small intestine; onepatient with a visceral myopathy had EBV DNA in both the small and large intestine; and one patient with a visceral myopathy had CMV DNA in the small intestine. No patient had evidence of VZV or HSV. Positive controls were all positive as expected. Patient cancer controls were negative for all viruses tested. 
A
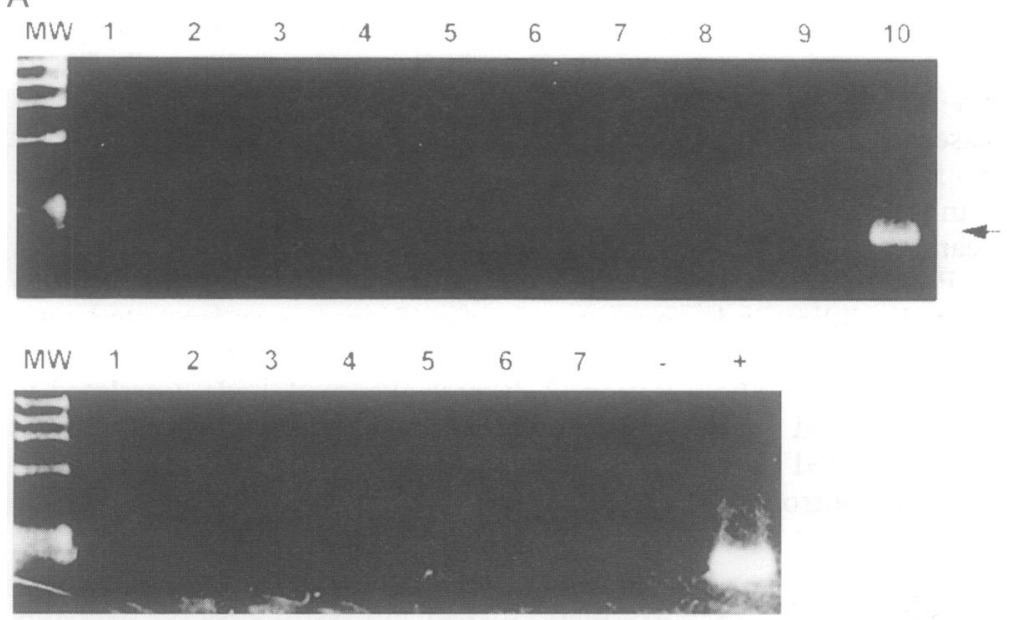

B

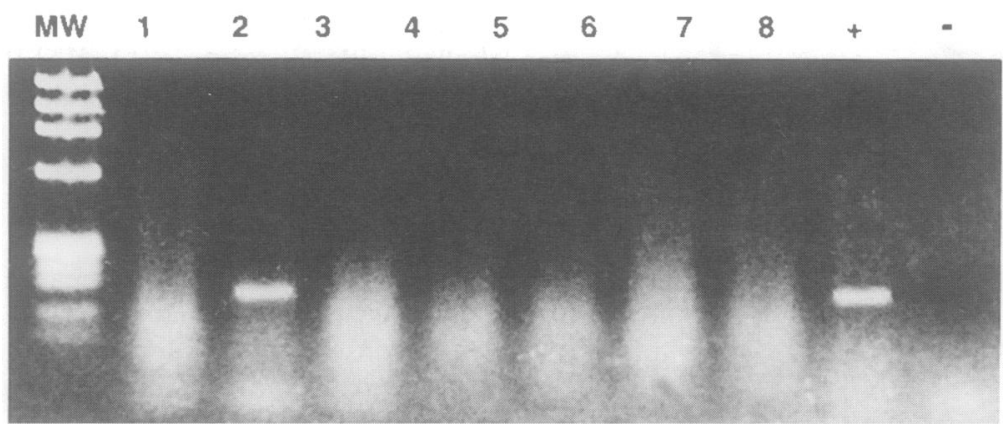

Figure 3: (A) Results of nested PCR for EBV DNA. Top panel from patient; bottom panel from control. DNA size markers (M), (+) control from EBV infected cell line and (-) control. A specific band of 112 base pairs is seen in lane 10 (arrow). (B) Results of nested $P C R$ for CMV DNA. DNA size markers $(M),(+)$ control from $C M V$ infected cell line and (-) control. A specific band of 168 base pairs is seen in lane 2 .

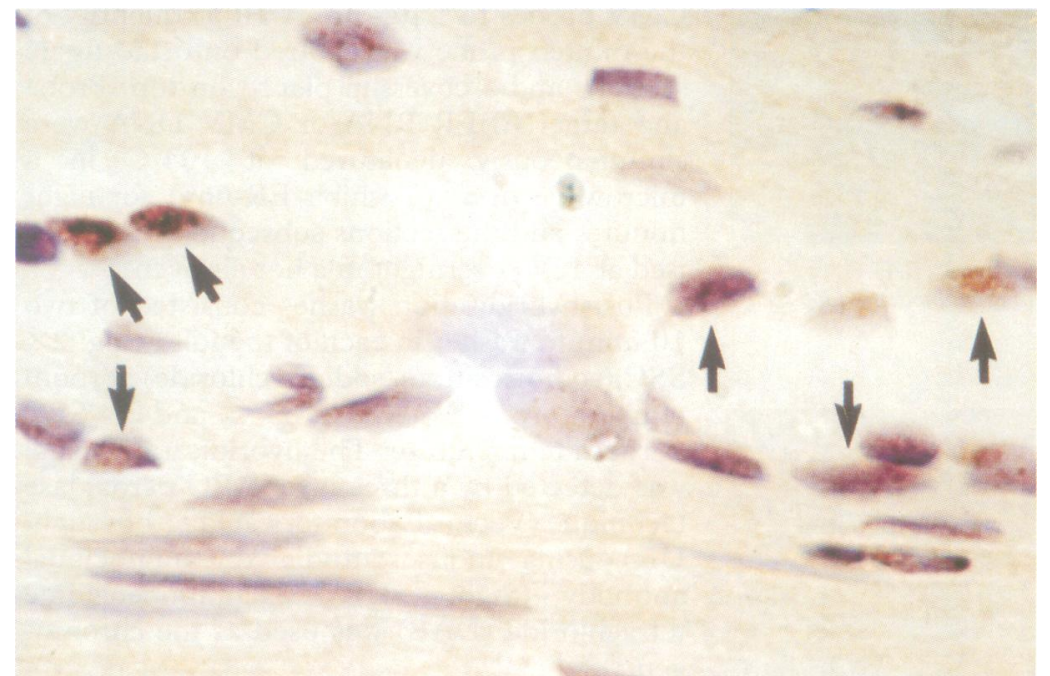

Figure 4: In situ hybridisation of small intestine from patient $3(\mathrm{RA})$ demonstrating positive nuclear signal (brown) for EBV (EBER 1 and 2) from Schwann cells in the myenteric

plexus. The positive staining Schwann cells are indicated by arrows. There is a clear absence of background staining.

ISH demonstrated localisation of the EBV probe (EBER) to the myenteric plexus in one of these PCR positive subjects (RA), in both the small and large intestine (fig 4). Despite a negative PCR result we also performed ISH on tissue from those patients who initially presented with an acute illness but as expected there was no localisation of virus using this less sensitive method.

\section{Discussion}

The aetiology of sporadic CIIP is unknown and most non-paediatric populations probably represent a heterogeneous group of patients. Some patients have an acute initial presentation with altered bowel habit and vomiting. As a chronic syndrome evolves a viral aetiology is suspected when no developmental, immunological, thrombotic, or endocrinological cause can be defined. Delayed serological investigation is difficult to interpret and intestinal biopsy specimens may lack the classic features of a viral cytopathic effect.

There have been few cases where serological testing has been used and to our knowledge no studies using direct viral culture or molecular techniques. This is the first systematic attempt to define a viral aetiology of CIIP using molecular techniques. We have demonstrated evidence suggestive of a herpes virus aetiology in some patients. On screening three patients were positive by PCR for EBV and CMV and in one patient with an inflammatory plexitis EBV signal localised to the myenteric plexus. This last patient provided the most convincing evidence of a viral pathogenesis, because of histological localisation of the virus to the affected tissue. There was no localisation of signal to the muscularis propria in that patient. We still cannot attribute a definite causal relationship of the virus to the disease, but believe this provides strong supportive evidence.

Positive PCR screening of affected tissue needs to be confirmed by tissue localisation to implicate a virus in pathogenesis. In sporadic CIIP classic cytopathic effects of viruses are usually absent though viruses need not cause distortion of cellular architecture to disrupt function. ${ }^{21}$ Tissue injury and necrosis may be caused by host immunological response rather than a direct action of the virus. In our case the inflammatory changes seen on biopsy correlated with the molecular findings and may indicate a degree of viral load that has allowed detection within the limitations of our system.

The likely explanation for the positive PCR but negative ISH findings in the other cases is that these patients had previous exposure to CMV or EBV and the exquisite sensitivity of PCR has amplified low copy numbers of virus DNA in intestinal lymphocytes. This would be related to the high general incidence of these viruses in the population and unrelated to the presence of CIIP. Alternatively the limitation may be in the sensitivity of ISH. Data pertaining to the background incidence of herpes virus DNA by PCR and ISH in normal control subjects and in disease states are sparse and conflicting. There is also little information correlating these molecular techniques to serological status in control populations. Wakefield et $a l,{ }^{27}$ in assessing the incidence of herpes virus infection in patients with inflammatory bowel disease by PCR, used resected specimens of large intestine of a control group of 21 patients with non-inflammatory bowel disease. Of these controls, $29 \%$ were positive for $\mathrm{CMV}$, and $19 \%$ for EBV; none of the patients tested positive for HSV1 or VZV. 
The choice of control material is difficult. Patients with inflammatory bowel disease are not suitable as the breeched mucosal barrier may allow entry of commensal viruses. Patients with other motility disorders are also not suitable as it is unknown to what extent viruses play a role in disorders such as irritable bowel syndrome or constipation. The ideal control for findings such as our own would be to study patients who have had proven previous EBV infection who undergo bowel resection for a non-motility disorder; the lack of EBV localising to their myenteric plexus would then be convincing evidence that our findings have true aetiological significance.

We found no evidence for viral DNA in our cancer control tissues. Similarly Robey et $\mathrm{al}^{28}$ in studying CMV colitis, found no evidence of CMV DNA by immunostaining or in situ hybridisation in a control population of 20 patients with fulminant ulcerative colitis. It is unlikely that the negative PCR results are related to tissue sampling problems. The sensitivity of detecting viral DNA on an individual biopsy sample may be low in a random or multifocally distributed disease process but in our study multiple blocks were examined from large surgically resected specimens of both small and large intestine. Eight of the 13 patients studied $(61 \%)$ had both small intestine and large intestine examined. We acknowledge the difficulty of performing and interpreting ISH on archival material but ISH on paraffin wax blocks using these probes has been done previously with success and is an established technique. ${ }^{29}$

The relationship between viral infection and autonomic dysfunction is rare but is probably under reported. Acute infectious mononucleosis can be complicated by a self limiting autonomic neuropathy. Neurological patients with chronic dysautonomic syndromes can have features similar to CIIP. These are of unknown aetiology but may be virally induced. In a 23 year old male with selective cholinergic dysautonomia Vassallo et $a l^{17}$ demonstrated serological evidence of infectious mononucleosis. This patient developed dysphagia, multiple episodes of subacute bowel obstruction, and autonomic nervous system dysfunction with visual disturbance, dilated pupils, and difficulty with micturition. Small bowel manometry revealed a neuropathic pattern and tests of autonomic nervous system function confirmed selective cholinergic dysautonomia with preservation of sympathetic activity. Histology did not reveal abnormalities of the myenteric plexus although silver staining was not performed, and no tissue studies for the presence of viruses were performed.

Visceral involvement concurrent with cutaneous VZV has been documented as a cause of disturbed motility of the stomach, small bowel, colon, and anus. ${ }^{30-33}$ Resolution usually parallels the improvement of cutaneous lesions. Cell bodies of both cutaneous and visceral afferent nerve fibres reside in the dorsal root ganglion and impaired motor function may be related to involvement of extrinsic enteric nerves to the affected viscera. However viral inclusions have also been isolated in the myenteric plexus itself in association with small bowel obstruction ${ }^{18}$ in a patient with overwhelming VZV infection.

CMV is a ubiquitous virus and up to $80 \%$ of normal individuals have elevated serum complement fixation antibody titres to CMV. It has been implicated serologically as causing acquired CIIP in an immunosuppressed patient who had undergone orthotopic heartlung transplantation. ${ }^{21}$ The reported finding of myenteric plexus nuclear inclusions in patients with CIIP and neurological syndromes ${ }^{34}$ has raised the suspicion of CMV being involved in the pathogenesis of some cases of sporadic CIIP. CMV inclusions have also been localised to the myenteric plexus of the entire small and large bowel in a renal transplant patient. ${ }^{20}$ In this patient light microscopy showed minimal mucosal abnormality, but classic basophilic intranuclear inclusions surrounded by clear halos and the typical electron microscopic appearances of CMV viral particles were demonstrated in the myenteric plexus. Acquired CIIP has been described in an infant with CMV who had an abnormal myenteric plexus on rectal biopsy with pale neurones, thick nerve processes, axonal dilatation, Schwann cell hyperplasia, and intranuclear inclusions surrounded by a distinct halo, ${ }^{19}$ and in an immunosuppressed patient who had undergone orthotopic heart-lung transplantation. ${ }^{21}$ The detection of CMV in colonic tissues is usually made by morphological identification of typical intranuclear inclusions in cells with well developed infection. However this has been shown in other organ systems to be a relatively insensitive diagnostic technique. ${ }^{35}$ The presence of virus has also been demonstrated by in situ hybridisation in cells without morphological evidence of infection. ${ }^{36}$ These techniques have not been extensively applied in the diagnosis of colonic disease.

In conclusion there is a body of evidence suggesting a role for herpes viruses in CIIP. We have found definite evidence of EBV involving the myenteric plexus in one patient with a visceral neuropathy. DNA viruses may be aetiological agents in the pathogenesis of some cases of this chronic condition and our findings suggest a state of restricted replication in view of the long history. The molecular techniques used do not enable us to determine confidently if active replication was ongoing. Treatment of sporadically occurring motility disorders with antiviral agents is a tantalising option.

Of great interest is the recent description of enterovirus sequences in tissue from patients with chronic neurological disorders involving the spinal $\operatorname{cord}^{5}$ and from cardiac muscle in patients with idiopathic cardiomyopathy. ${ }^{37}$ Further examination of tissue for enteroviruses should also be performed in patients with CIIP to look for evidence of viral damage to extrinsic nerves, particularly in view of the high incidence of autonomic dysfunction in this condition. ${ }^{15}$

Henry Debinski was supported by the Association of Commonwealth Universities. 
1 Schuffler MD. Chronic intestinal pseudo-obstruction syndromes. Med Clin North Am 1981; 65: 1331-58.

2 Schuffler MD, Rohrmann CA, Chaffee RG, Brand DI Delaney $\mathrm{JH}$, Young $\mathrm{JH}$. Chronic intestinal pseudoobstruction. A report of 27 cases and review of the literature. Medicine (Baltimore) 1981; 60: 173-96.

3 Heitlinger LA, Juhling McClung $\mathrm{H}$, Murray $\mathrm{RD}, \mathrm{Li}$ BUK Recurrent pancreatitis in three patients with chronic idiopathic intestinal pseudo-obstruction. $\mathcal{F}$ Pediatr Gastroenterol Nutr 1991; 13: 92-5.

4 Shimotake T, Iwai N, Yanagihara J, Tokiwa K, Fushiki S. Biliary tract complications in patients with hypoganglionosis and chronic idiopathic intestinal pseudonosis and chronic idiopathic intestinal pseudo-

5 Dudley HA, Sinclair IS, McLaren IF. Intestinal pseudoobstruction. F R Coll Edinb 1958; 3: 206-17.

6 Schuffler M. Intestinal pseudo-obstruction. Ital $\mathcal{f}$ Gastroenterol 1989; 21: 35-41.

7 Krishnamurthy S, Schuffler M. Pathology of neuromuscula disorders of the small intestine and colon. Gastroenterology 1987; 93: 610-39.

8 Schuffler M, Lowe M, Bill A. Studies of idiopathic intestina pseudo-obstruction I. Hereditary hollow visceral myopathy: clinical and pathological studies. Gastroenterology 1977; 73: 327-38.

9 Schuffler M, Pope C. Studies of idiopathic intestina pseudo-obstruction II. Hereditary hollow visceral myopathy: family studies. Gastroenterology 1977; 73: myopathy:

$10 \mathrm{Li} \mathrm{V}$, Hostein J, Romero NB, Marsac C, Mezin P, Bost R, et al. Chronic intestinal pseudo-obstruction with myopathy and ophthalmoplegia. A muscle biochemical study of a mitochondrial disorder. Dig Dis Sci 1992; 37: 456-63.

11 Cervera R, Bruix J, Bayes A, Blesa R, Illa I, Coll J, et al. Chronic intestinal pseudo-obstruction and ophthalmoplegia in a patient with mitochondrial myopathy. Gut 1988; 29: 544-7.

12 Lowsky $R$, Davidson G, Wolman S, Jeejeebhoy $\mathrm{KN}$, Hegele RA. Familial visceral myopathy associated with mitochondrial myopathy. Gut 1993; 34: 279-83.

13 Smith VV, LB Kamm, MA, Nicholls RJ. Intestinal pseudoobstruction with deficient smooth muscle alpha-actin. Histopathology 1992; 21: 535-42.

14 Smith B. The neuropathology of the alimentary tract. London: Edward Arnold, 1972

15 Bharucha AE, Camilleri M, Low PA, Zinmeister AR. Autonomic dysfunction in gastrointestinal motility disorders. Gut 1993; 34: 397-401.

16 Robertson CS, Martin BA, Atkinson M. Varicella-zoster virus DNA in the oesophageal myenteric plexus in virus DNA in the oesophageal

17 Vassallo M, Camilleri M, Lynn Caron B, Low PA. Gastrointestinal motor dysfunction in acquired selective cholinergic dysautonomia associated with infectious mononucleosis. Gastroenterology 1991; 100: 252-8.

18 Chang AE, Joung NA, Reddick RL, Orenstein JM, Hosea SW, Katz P, et al. Small bowel obstruction as a complication of disseminated varicella-zoster infection. Surgery 1978; 83: 371-4.

19 Sonsino E, Mouy R, Foucaud P, Cezard JP, Aigrain V, Bocquet $\mathrm{L}$, et al. Intestinal pseudo-obstruction related to cytomegalovirus infection of myenteric plexus. $N$ Engl $\mathcal{F}$ Med 1984; 311: 196-7.
20 Press MF, Riddell RH, Ringus J. Cytomegalovirus inclusion disease. Its occurrence in the myenteric plexus of a renal transplant patient. Arch Pathol Lab Med 1980; 104 580-3.

21 Mathias JR, Baskin GS, Reeves-Darby VG, Clench MH, Smith LL, Calhoon JH. Chronic intestinal pseudoobstruction in a patient with heart-lung transplant. Therapeutic effect of leuprolide acetate. Dig Dis Sci 1992; 37: 1761-8.

22 Debinski H, Ahmed S, Milla PJ, Kamm MA. Electrogastrography in chronic idiopathic intestinal pseudogastrography in chronic idiopathic int

23 Saiki RK, Gelfand DH, Stoffel S, Scharf SJ, Higachi R, Horn GT, et al. Primer-directed enzymatic amplification Horn GT, et al. Primer-directed enzymatic amplification 1988; 239: 487-91.

24 Harper DR, Kangro HO, Heath RB. Serological responses in varicella and zoster assayed by immunoblotting. $\mathcal{F ~} \mathrm{Med}$ Virol 1988; 25: 387-8.

25 Khan G, Coates PJ, Kangro HO, Slavin G. Epstein Bar virus (EBV) encoded small RNAs: targets for detection by in situ hybridisation with oligonucleotide probes. $\mathcal{F}$ Clin Pathol 1992; 45: 616-20.

26 Coates PJ, Mak WP, Slavin G, d'Ardenne AJ. Detection of single copies of Epstein-Barr virus in paraffin wax sections by non-radioactive in situ hybridization. 7 Clin Pathol 1991; 44: 487-91.

27 Wakefield AJ, Fox JD, Sawyer AM, Taylor JE, Sweenie CH, Smith $M$, et al. Detection of herpesvirus DNA in the large intestine of patients with ulcerative colitis and Crohn's intestine of patients with ulcerative colitis and Crohn's Virol 1992; 38: 183-90.

28 Robey SS, Gage WR, Kuhaja FP. Comparison of immunoperoxidase and DNA in situ hybridization techniques in peroxidase and DNA in situ hybridization techniques in the diagnosis of cyto

29 Khan G, Norton AJ, Slavin G. Epstein-Barr virus in Hodgkin disease. Relation to age and subtype. Cancer 1993; 71: 3124-9.

30 Kebede D, Barthel JS, Singh A. Transient gastroparesis associated with cutaneous herpes zoster. Dig Dis Sci 1987 32: 318-22.

31 Pai NB, Murthy RSN, Girish Kumar HT, Gerst PH. Association of acute colonic pseudo-obstruction (Ogilvie's syndrome) with herpes zoster. Am Surg 1990 56: $691-4$.

32 Ceccese WJ, Bronzo RL, Wadler G. Ogilvie's syndrome associated with herpes zoster infection. F Clin Gastroenterol 1987; 7: 309-13.

33 Jellinek EH, Tulloch WS. Herpes zoster with dysfunction of bladder and anus. Lancet 1976; 2: 1219-22.

34 Schuffler MD, Bird TD, Sumi SM, Cook A. A familial neuronal disease presenting as intestinal pseudoneuronal disease presenting as intestinal

35 Shulman HM, Hackman RC, Sale GE, Meyers JD. Rapid cytologic diagnosis of cytomegalovirus interstitia

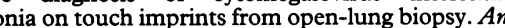
f Clin Pathol 1982; 77: 90-4

36 Myerson D, Hackman RC, Nelson JA, Ward DC, McDougall JK. Widespread presence of hisologically occult cytomegalovirus. Hum Pathol 1984; 15: 430-9.

37 Schultheiss H, Hofschneider P. Diagnosis of enterovirus heart disease by in situ nucleic acid hybridization. Circulation 1988; 76: 1044 . 